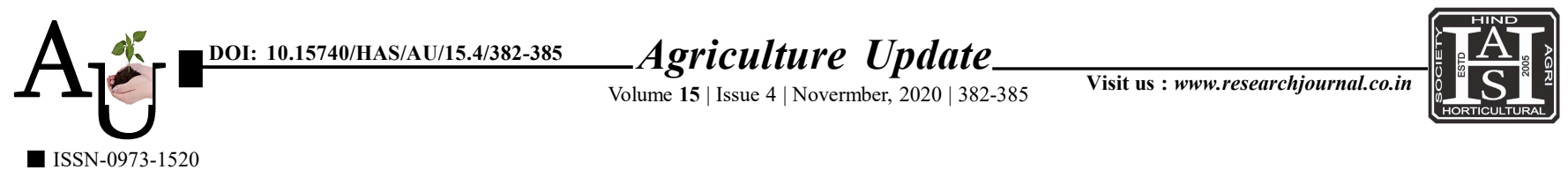

\title{
Research article: Studies on awareness of farmers pertaining agriculture management related information in Bundelkhand tract of Uttar Pradesh
}

Article Chronicle : Received :

15.02.2020;

Revised:

03.10.2020;

Accepted :

$22 . .10 .2020$

KEY Words :

Awareness,

Co-operative

agriculture, Market

place, Telepathy

system, T.V. channels, Video conferencing
Author for correspondence :

\section{R.A. Singh}

C.S. Azad University of

Agriculture and

Technology, Kanpur

(U.P.) India

Email: rajpals567@gmail.

com

See end of the article for authors' affiliations
SUMMARY : The study was undertaken in districts Jalaun and Hamirpur in Bundelkhand tract of Uttar Pradesh. Results display that the farmers were unaware about the availability of quality seed and the place from where it could be purchased. Similarly, the unawareness was quite significant about pesticides, horticulture nursery and farm implements. Most of farmers (87.50\%) were aware about market place, where they could sell from produced. Likewise, awareness was higher towards transport facilities. Unawareness was quite high among farmers $(90.00 \%)$ about market laws, percentage of interest and repayment norms. The farmers need to be made aware on regular basis about different programmes related to oilseeds, pulses, food grains etc., so that they could avail different kinds of subsidy and facilities like training exposure visit etc. besides of project related technologies.

How to cite this article : Pal, S.B., Singh, Lakhan and Singh, R.A. (2020). Studies on awareness of farmers pertaining agriculture management related information in Bundelkhand tract of Uttar Pradesh. Agric. Update, 15(4): 382-385; DOI : 10.15740/HAS/AU/15.4/382-385. Copyright@ 2020: Hind Agri-Horticultural Society. 